\title{
Homoki gyepek regenerációjának hosszú távú sikeressége felhagyott szántókon: kezdeti restaurációs beavatkozások és a táji környezet hatásai
}

\author{
Sáradi Nóra ${ }^{1 *}$, Yesenia Belén Llumiquinga ${ }^{2}$, Bruna Paolinelli \\ Reis $^{2}$, Török Katalin ${ }^{3}$, Szitár Katalin ${ }^{4}$, Csákvári Edina ${ }^{3}$ és Halassy \\ Melinda ${ }^{3}$ \\ ${ }^{1}$ Magyar Agrár- és Élettudományi Egyetem, Növénytermesztési-tudományok Intézet, \\ 2100, Gödöllö, Páter Károly u. 1. \\ ${ }^{2}$ Eötvös Loránd Tudományegyetem, Növényrendszertani, Ökológiai és Elméleti Biológiai \\ Tanszék, 1117 Budapest, Pázmány Péter sétány 1/C \\ ${ }^{3}$ Ökológiai Kutatóközpont, Ökológiai és Botanikai Intézet, \\ 2163 Vácrátót, Alkotmány u. 2-4. \\ ${ }^{4}$ Ökológiai Kutatóközpont, Ökológiai és Botanikai Intézet, Lendület Táj és \\ Természetvédelmi Ökológiai Kutatócsoport, 2163 Vácrátót, Alkotmány u. 2-4. \\ *E-mail:saradi.nora@ecolres.hu
}

Összefoglaló: Kutatásunkban három kezeléstípus hatását vizsgáltuk kiskunsági homoki gyepek felhagyott szántókon történő helyreállításában, 16 évvel a beavatkozások megkezdése után. Elemeztük a kezelések edényes növények fajgazdagságára, boritására, valamint a honos célfajok és az özönnövények relatív borítására gyakorolt hatását. A kezelések két különböző korú felhagyott szántón folytak 2002 és 2008 között. A két terület táji környezetének élőhely-összetételét és inváziós fertözöttségét is összevetettük. Hosszú távú eredményeink alapján a magvetés bizonyult a leghatásosabb módszernek a homoki gyepek helyreállításában. A kaszálást és a szénforrás-adagolást a vetést kiegészítő beavatkozásokként javasoljuk. Az elemzett mutatók többsége helyspecifikus fejlődést mutatott, ami összefügghet a felhagyott szántók korával és táji adottságaival. Eredményeink alapján a homoki gyepek helyreállítása felhagyott szántókon kisebb magbeviteli egységekkel is megvalósítható.

Kulcsszavak: gyeprestauráció, özönnövények, szántó-restauráció, homokpusztagyep, hosszú távú monitorozás

\section{Bevezetés}

Az elörejelzések szerint Európában 2015 és 2030 között a mezőgazdasági területek mintegy 11\%-át fogják kivonni a müvelésből (Perpiña et al. 2018). Közép- és 
Kelet-Európában a szocialista rendszerek bukása egyértelmủen felgyorsította a földterületek felhagyásának mértékét, amikor az állami tulajdonban álló mezögazdasági szövetkezetek összeomlottak (Valkó et al. 2016a, Mihók et al. 2017). A mezőgazdasági tevékenység megszünése teret enged a spontán vegetációfejlödésnek.

A felhagyott szántóterületek vegetációdinamikáját és a kialakuló növényközösséget a korábbi múvelési módok, a vegetáció, a talaj és a többi abiotikus jellemzö, valamint a táji kapcsolatok együttesen határozzák meg (Cramer et al. 2008). A felhagyott szántók sajátos, átmeneti ökoszisztémát jelentenek (Clark 2017), melyek általában hosszú távon is különbözőek maradnak az elsődleges gyepterületektől (Csathó 2011, Csecserits et al. 2011). A felhagyott szántók lehetőséget teremtenek az őshonos fajok újbóli megtelepedésére, ami csökkentheti a táji fragmentációt, ugyanakkor az inváziós fajok megtelepedésének esélye is fennáll (Csecserits et al. 2011).

A spontán regeneráció sikerét a fajok terjedési képességével, megtelepedési és túlélési adottságaikkal kapcsolatos tényezők korlátozzák az adott környezeti tényezők függvényében (Cramer és Hobbs 2007). A talajban felhalmozódó tápanyagfelesleg az egyik legkritikusabb környezeti tényező a felhagyott szántók regenerációjában, mivel hozzájárul a kompetíciós viszonyok átrendezéséhez és az özönnövények elterjedéséhez is (Davis et al. 2000). Az özönnövények terjedésén és a magas tápanyagforrás melletti erős kompetíción túlmenően a propagulumlimitáció korlátozza a spontán regenerációt (Török et al. 2018, Halassy et al. 2019). A honos fajok magjainak jelenléte nagymértékben függ a felhagyás időpontjától, a terület méretétöl (Cramer et al. 2008), továbbá a müvelési idő hosszától, mivel a magbank és a felszíni növényzet a hosszú ideig tartó müvelés alatt elszegényedik (Bakker és Berendse 1999). A gyepekben előforduló fajok többsége nem képez állandó magbankot, ellenben a szántóföldek magbankja nagy mennyiségben tartalmaz gyommagvakat (Csontos et al. 2016, Valkó et al. 2021). A felhagyott szántók vegetációfejlődése során tehát a magbankból való regeneráció helyett elsődleges a célfajok kívülről történő beterjedése, ami csak ott lehetséges, ahol a természetes növényzet maradványai még mindig jelen vannak a tájban (Török et al. 2018). Ugyanakkor, a táji környezet veszélyeztetheti a spontán regenerációt, amennyiben jelentős a tájban az inváziós fertőzöttség (Csecserits et al. 2016).

Aktív restaurációs beavatkozásokkal ezek a korlátok többnyire leküzdhetők, és a gyepek biodiverzitása helyreállítható (Cramer et al. 2008). Magvetéssel bevihetők a magbankból hiányzó, vagy a táji akadályok miatt a területre be nem jutó propagulumok (Török et al. 2010, Kövendi-Jakó et al. 2019). A talaj tápanyagtartalma csökkenthető pl. a feltalaj eltávolításával vagy szénforrás bevitelével (Perry et al. 2010, Halassy et al. 2021). A szénforrás-adagolás lényege, hogy stimulálja 
a talajlakó mikroorganizmusok aktivitását, melyek eközben a talajban felvehető nitrogént is megkötik, így időlegesen kevesebb lesz a növények által felvehető nitrogén a talajban (Török et al. 2000, 2014). Kaszálással növelhető a faji diverzitás, mivel új fajok megtelepedésére alkalmas mikroélőhelyeket hoz létre a gyepszőnyegben (Kelemen et al. 2014), Ugyanakkor a táji környezet jelentősen befolyásolhatja a restaurációs beavatkozások sikerét, mind pozitív irányban a célfajok spontán betelepedése révén, mind negatív irányban, amennyiben az inváziós fajok megjelenése várható.

Jelen kutatás célja, hogy a kezdeti magvetés, kaszálás és szénforrás-adagolás hosszú távú hatását értékeljük homoki gyepek felhagyott szántókon történő helyreállításában, 16 évvel az első beavatkozások után, ill. értékeljük a területek közti különbségeket a táji környezet eltérései alapján. A következő kérdéseket vetettük fel:

- Hogyan befolyásolja a kezdeti magvetés, kaszálás és szénforrás adagolása hosszú távon a terület fajgazdagságát, az edényes növények borítását, valamint a cél- és inváziós fajok relatív borítását?

- Milyen eltérések vannak a kísérleti területek táji jellemzői (élőhely-összetétel és inváziós fertőzöttség) között és ezek hogyan befolyásolják a gyepregeneráció sikerességét?

\section{Anyag és módszer}

A kísérleti terület a Kiskunsági Nemzeti Park Fülöpházi-buckavidékén található (1. ábra). Az élőhely-helyreállítási kísérletek eredetileg három felhagyott szántón folytak, viszont az egyik terület (a legfiatalabb felhagyás) 2008-tól ismét müvelésbe lett vonva, ezért hosszú távon nem volt értékelhető. A másik két szántóterület légifotók alapján az 1990-es évek végén, illetve az 1980-as években kerülhetett felhagyásra. A közepes korú felhagyás $105 \mathrm{~m}$, az idősebb $110 \mathrm{~m}$ tengerszint feletti magasságon helyezkedik el. A közepes korú felhagyás talaja iszapos durvahomok és finom szemcséjủ homok, továbbá homokos agyag- és iszapréteget találtunk 120-170 cm mélyen. Az idősebb felhagyás talaja durva homok és homok, 260 és $270 \mathrm{~cm}$ között konkréciókkal. A két terület egyéb talajváltozói hasonlóak voltak (Halassy et al. 2016, Llumiquinga et al. 2021). A továbbiakban a közepes korú felhagyást „A” területnek, az idősebb felhagyást „B” területnek fogjuk nevezni.

2002 szeptemberében előkezelésként egy-egy $400 \mathrm{~m}^{2}$-es területet beszántottak a felhagyott szántókon a felszíni vegetáció eltávolítása érdekében. A szántott területeken belül $8 \times 8 \mathrm{db} 1 \mathrm{~m}^{2}$-es parcellát jelöltünk ki a kezeléseknek, közöttük 1 méteres hézagokkal. Egy soron belül nyolcféle kezelési típust rendeltünk vélet- 


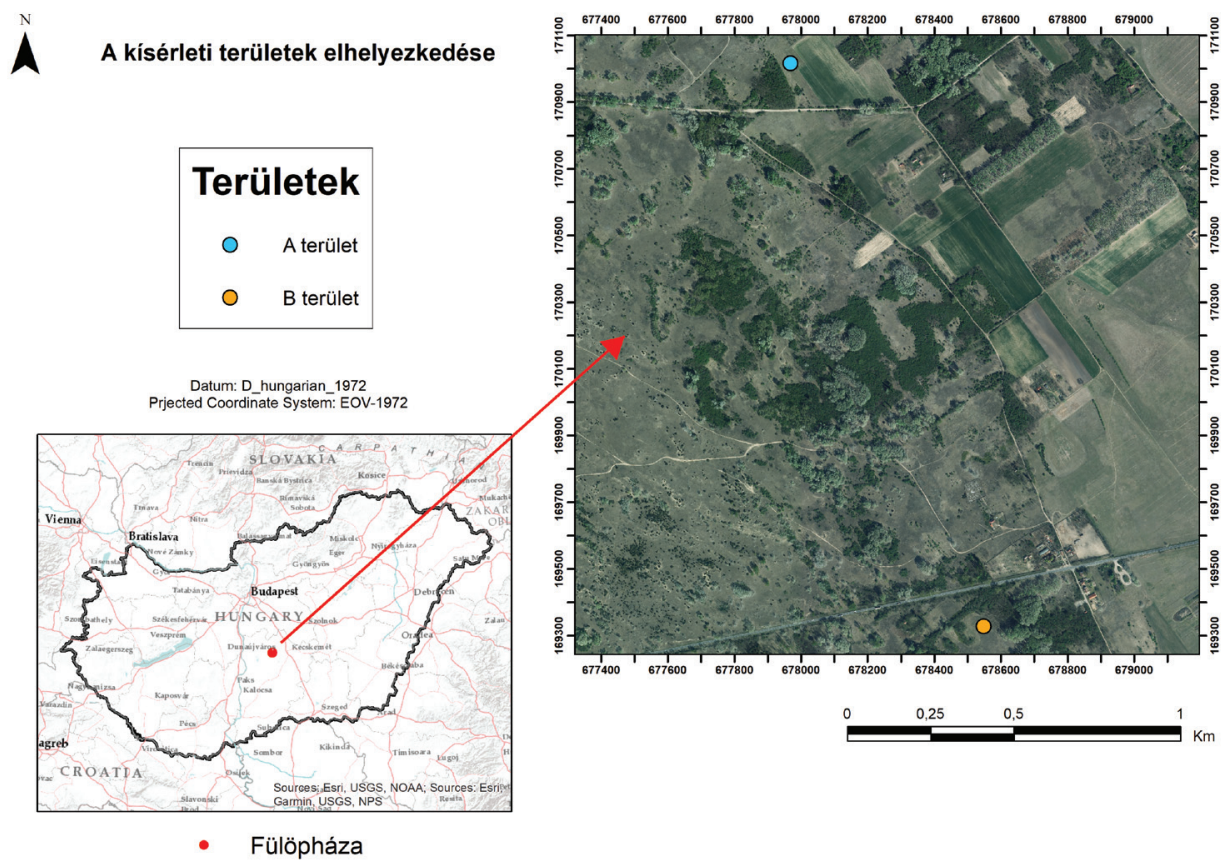

1. ábra. A kísérleti területek elhelyezkedése a Kiskunsági Nemzeti Park Fülöpházi-buckavidék területén. A két színes kör a két felhagyott szántóterületet jelöli a légifotón.

lenszerủen a nyolc parcellához, a nyolc oszlop ezek véletlenszerủen elrendezett ismétlései. A kísérleti elrendezés mindkét terület esetében azonos volt. Az alkalmazott kezelések: kezelés nélküli kontrol (Ko), Vetés (V), Kaszálás (K), Szénforrás-adagolás (Sz), valamit ezek kombinációi (VK, VSz, KSz, VKSz). A vetett parcellákban összesen öt homoki fajt vetettünk el a kísérlet elején, 2002 szeptemberében: Festuca vaginata Waldst. et Kit. ex Willd., $1809\left(1,55 \mathrm{~g} / \mathrm{m}^{2}\right)$, Stipa borysthenica Klokov ex Prokudin, 1951 (1,05 g/m²), Koeleria glauca (Spreng.) DC., $1813\left(1,00 \mathrm{~g} / \mathrm{m}^{2}\right)$, Dianthus serotinus Waldst. \& Kit., 1804 és Euphorbia segueriana Neck., 1770 (a két faj együtt $0,20 \mathrm{~g} / \mathrm{m}^{2}$ ). A 2003-as erős aszály alatt a S. borysthenica magoncok kipusztultak, emiatt a fajt 2003 szeptemberében ismételten elvetettük $\left(1,31 \mathrm{~g} / \mathrm{m}^{2}\right)$. Kaszálást az első évben kétszer (június, szeptember eleje), majd 2004 és 2008 között évente egyszer (szeptember eleje) alkalmaztunk. A parcellaméret miatt sarlót használtunk, a kaszálékot pedig eltávolítottuk a parcellákról. A szénforrás-adagolás háromhetente történt április és október között 2003-tól 2008-ig. Egy-egy alkalommal 45 g/m² cukrot használtunk fel parcellánként. Az elemzésekben a fő kezeléseket elemeztük külön-külön. A kísérleti módszerekkel kapcsolatban bővebb leírás található Halassy et al. 2016 és 2019 közleményeiben. 
Az edényes növényfajok százalékos borítását valamennyi $1 \mathrm{~m}^{2}$-es parcellában megbecsültük a nyár eleji és nyár végi aszpektusban (2019. június 4-7. és augusztus 26-28.). A korábbi elemzésekhez hasonlóan fajonként az évi maximális borítással számoltunk (Halassy et al. 2016). A fajgazdagságot a parcellánkénti fajszámmal fejeztük ki. Az edényes fajok borítását a faji szinten becsült borítási értékek összegével fejeztük ki. Mivel a növények több rétegben is növekedtek, és az évi maximális borítási értékkel számoltunk, ezért a teljes borítás esetenként meghaladhatta a 100\%-ot. A célfajok a korábbi kutatások (Csecserits et al. 2011, Halassy et al. 2016) alapján kerültek meghatározásra, és a csoportot tovább bontottuk vetett és nem vetett fajokra. Az özönnövények elemzésekor a neofita, vagyis 1492 után érkezett fajokat vettük figyelembe, melyek Balogh et al. (2004) munkája alapján kerültek meghatározásra. Egyéves, valamint évelő életforma-csoport szerint külön is elemeztük őket. Végül az öt vetett fajt és a domináns neofitákat egyenként is vizsgáltuk. A célfajok és özönfajok esetében a parcellánkénti relatív borítással számoltunk.

A táji környezet élőhelyi jellemzésére egy 500 m-es pufferterületet jelöltünk ki a kísérleti területek középpontja körül. A pufferterületen belül hét élőhelytípust különítettünk el Csecserits et al. (2011) élőhelytérképe alapján: agrárélőhelyek (A), másodlagos gyepek (MGy) (felhagyott szántókon kialakuló gyepek), erdészeti ültetvények (Ü), elsődleges (természetközeli) gyepek (TGy), természetközeli erdők (TE), vizes élőhelyek (V) és épített területek (É). Az élőhelytérképeket frissítettük a legfrissebb ortofotók (2019) alapján. A táji környezet inváziós fertőzöttségét transzekt módszerrel vizsgáltuk 2020 szeptemberében. Ehhez a kísérleti területek középpontjából 100 méter hosszúságú transzekteket feszítettünk ki a nyolc égtáj (É, ÉK, K, DK, D, DNY, NY, ÉNY) felé, majd a transzekt mentén $1 \mathrm{~m} \times 1$ m-es érintkező kvadrátokban rögzítettük az előforduló özönfajok egyedszámát. Az egyes élőhelytípusok területének kiszámítását és a domináns inváziós fajok tömegességének térképi ábrázolását QGIS szoftverrel végeztük.

A kezelések (magvetés, kaszálás és szénforrás-adagolás) és a terület, valamint az egyes kezelések területtel való interakciójának fajgazdagságra gyakorolt hatását általánosított lineáris modellekkel (GLM) teszteltük Poisson-eloszlás alkalmazása mellett. Az edényes növények borítása és a cél- és özönfajok relatív borítása esetén kétutas ANOVA-t használtunk. A szignifikáns interakcióval rendelkező eseteknél post hoc Tukey tesztet végeztünk. Ha csak a területnek vagy a kezelésnek volt szignifikáns hatása, akkor az adott tényezőre egyutas ANOVA-t alkalmaztunk. A nem vetett célfajok és az özönnövények relatív borításához négyzetgyök transzformációt alkalmaztunk. Az özönnövények transzektek menti abundanciáját negatív binomiális GLM segítségével számoltuk (Zuur et al. 2009). A statisztikai 
elemzéseket az R 3.6.0 verziójában az „nlme” kiegészítő csomaggal végeztük (R Core Team 2019, Pinheiro et al. 2017).

\section{Eredmények}

A vizsgálat során összesen 84 fajt azonosítottunk, ezek közül 36-ot célfajként, hatot pedig özönnövényként soroltunk be. Magasabb kvadrátonkénti átlagos fajszámot figyeltünk meg az „A” területen (20 faj), mint a „B” területen (14 faj). Szignifikáns hatása volt a terület-magvetés és a terület-kaszálás kölcsönhatásának, azonban a post hoc statisztikai teszt alapján a fajgazdagság csak a területek között különbözött (2. ábra).

Az edényes növények borítása szignifikánsan $(\mathrm{F}=20,430 \mathrm{p}<0,001)$ magasabb volt az „A " területen (112\%), mint a „B” területen (96\%), továbbá szignifikánsan $(\mathrm{F}=3,992 \mathrm{p}<0,05)$ magasabb a kaszált parcellákban (108\%) mint a nem kaszált parcellákban $(100,5 \%)$.

A területnek szignifikáns hatása volt a célfajok relatív borítására, kivéve a $F$. vaginata-t, ami mindkét területen domináns volt (1. táblázat). A „B” területen magasabb volt a célfajok, a nem vetett célfajok és a $S$. borysthenica relatív borítása, és alacsonyabb volt a $D$. serotinus és az $E$. segueriana relatív borítása az „A” területhez képest (1. táblázat). A három kezeléstípus közül csak a vetésnek volt szignifikáns hatása a vetett fajokra. A $S$. borysthenica magasabb borítást $(18,5 \%)$ ért el a vetett parcellákban, mint a nem vetettekben $(8,5 \%)$. Míg a $K$. glauca esetében pont ellenkezőleg, szignifikánsan magasabb borítást (3\%) mutatott a nem vetett parcellákban, mint a vetettekben $(2 \%)$. A vetés jelentős hatással volt a vetett fajok borítására a területtel való kölcsönhatásban is. A vetett fajok legmagasabb borítását $(73 \%)$ a „B” terület vetett parcelláiban találtuk, a legalacsonyabb borítását $(62,5 \%)$ pedig ugyanitt a nem vetett parcellákban (3. ábra). Az „A” terület parcellái köztes értékeket mutattak.

A terület szignifikáns hatást gyakorolt az özönnövényekre is (1. táblázat). Valamennyi özönfaj-kategória, így az egyéves, évelö és összes özönfaj együttes relatív borítása is nagyobb volt az „A" területen, mint "B" területen (1. táblázat). A kezelések közül csak a magvetésnek volt hatása az özönnövények relatív borítására, ezen belül is az egyéves fajokra. A relatív borítás szignifikánsan alacsonyabb $(\mathrm{F}=5,324$ $\mathrm{p}<0,05)$ volt a vetett parcellákon $(1,90 \%)$ mint a nem vetetteken $(3,87 \%)$, elsősorban az egyéves neofiták szignifikánsan alacsonyabb $(\mathrm{F}=10,86 \mathrm{p}<0,01)$ relatív borítása miatt $(0,93 \%$ a vetett és $2,28 \%$ a nem vetett parcellákon). Szignifikáns terület-vetés kölcsönhatás volt megfigyelhetö az Ambrosia artemisiifolia L., 1753 
a

Fajgazdagság

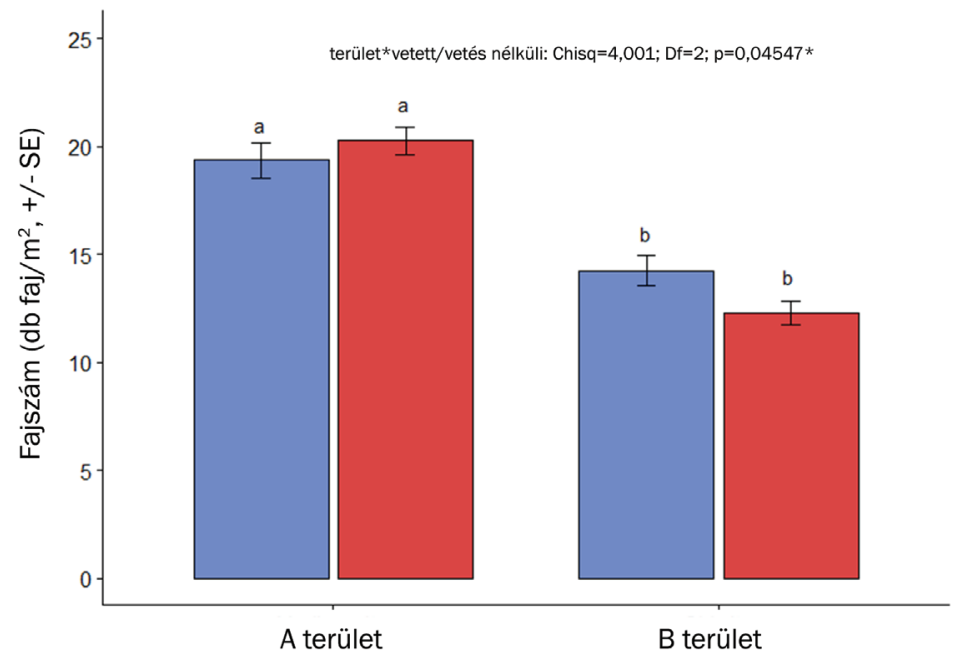

b

Fajgazdagság

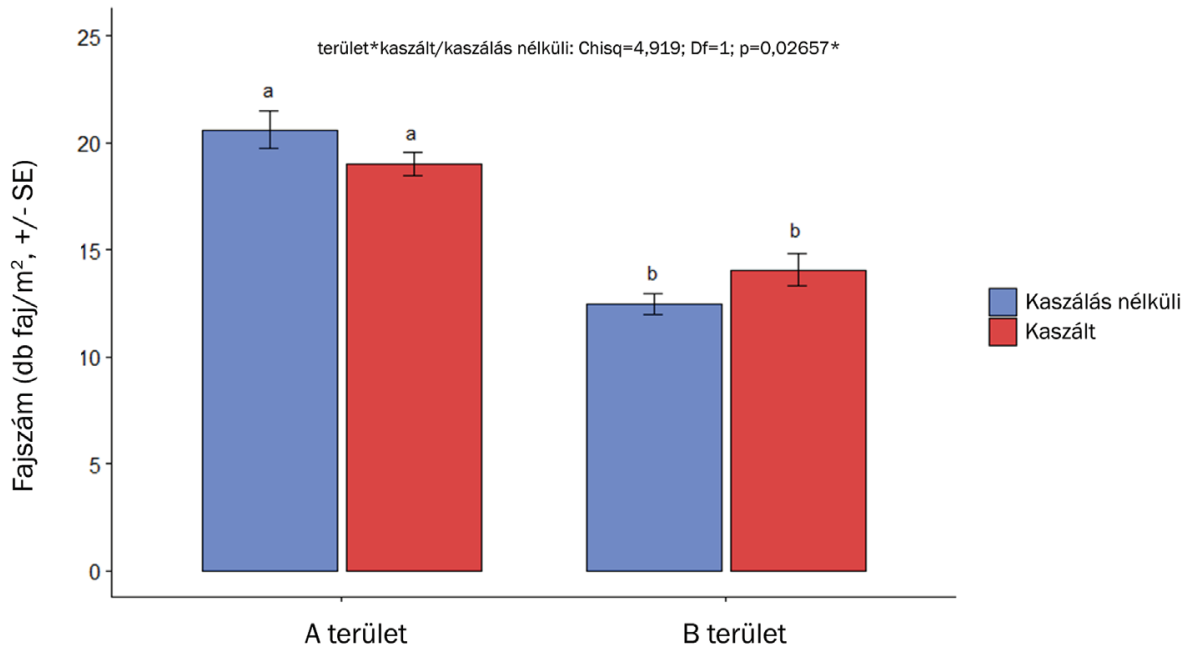

2. ábra. Fajgazdagság (a) a vetett és a vetés nélküli parcellákon, továbbá (b) a kaszált és kaszálatlan parcellákon az „A” és „B” terület esetében 2019-ben. A szignifikáns különbségeket ( $<<0,05)$ eltérő kisbetükkel jelöltük. 
1. táblázat. A célfajok és az özönnövények relatív borítása (\%) a két területen, 2019-ben és azok statisztikai különbsége ANOVA alapján. Csillaggal jelöltük azokat az indikátorokat, melyek szignifikáns interakciót mutattak a kezelések között is post hoc Tukey teszt alapján. Ezeket részletesen az ábrákon mutatjuk be.

\begin{tabular}{ccccc}
\hline & "A" terület & "B" terület & F-érték & $\mathrm{p}$-érték \\
\hline Célfajok & $85 \%$ & $92 \%$ & 12,83 & $\mathrm{p}<0,001$ \\
Nem vetett fajok & $15 \%$ & $24 \%$ & 17,21 & $\mathrm{p}<0,001$ \\
Összes vetett faj & $70 \%$ & $68 \%$ & 0,738 & $\mathrm{p}=0,392^{*}$ \\
Festuca vaginata & $46 \%$ & $44 \%$ & 0,294 & $\mathrm{p}=0,589$ \\
Stipa borysthenica & $10 \%$ & $17 \%$ & 7,960 & $\mathrm{p}<0,001^{*}$ \\
Koeleria glauca & $3,5 \%$ & $2,7 \%$ & 0,611 & $\mathrm{p}=0,436^{*}$ \\
Dianthus serotinus & $6,2 \%$ & $3,1 \%$ & 6,129 & $\mathrm{p}<0,05$ \\
Euphorbia segueriana & $3,4 \%$ & $0,0 \%$ & 62,95 & $\mathrm{p}<0,001$ \\
Özönnövények & $4,5 \%$ & $1,2 \%$ & 23,54 & $\mathrm{p}<0,001$ \\
Egyéves özönfajok & $2,0 \%$ & $1,2 \%$ & 14,16 & $\mathrm{p}<0,001$ \\
Ambrosia artemisiifolia & $1,5 \%$ & $1,2 \%$ & 8,329 & $\mathrm{p}<0,01 *$ \\
Conyza canadensis & $0,5 \%$ & $0,0 \%$ & 13,70 & $\mathrm{p}<0,001 *$ \\
Évelö özönfajok & $2,5 \%$ & $0,0 \%$ & 84,88 & $\mathrm{p}<0,001$ \\
Oenothera biennis & $0,9 \%$ & $0,0 \%$ & 33,02 & $\mathrm{p}<0,001$ \\
Asclepias syriaca & $1,7 \%$ & $0,0 \%$ & 61,93 & $\mathrm{p}<0,001$ \\
\hline
\end{tabular}

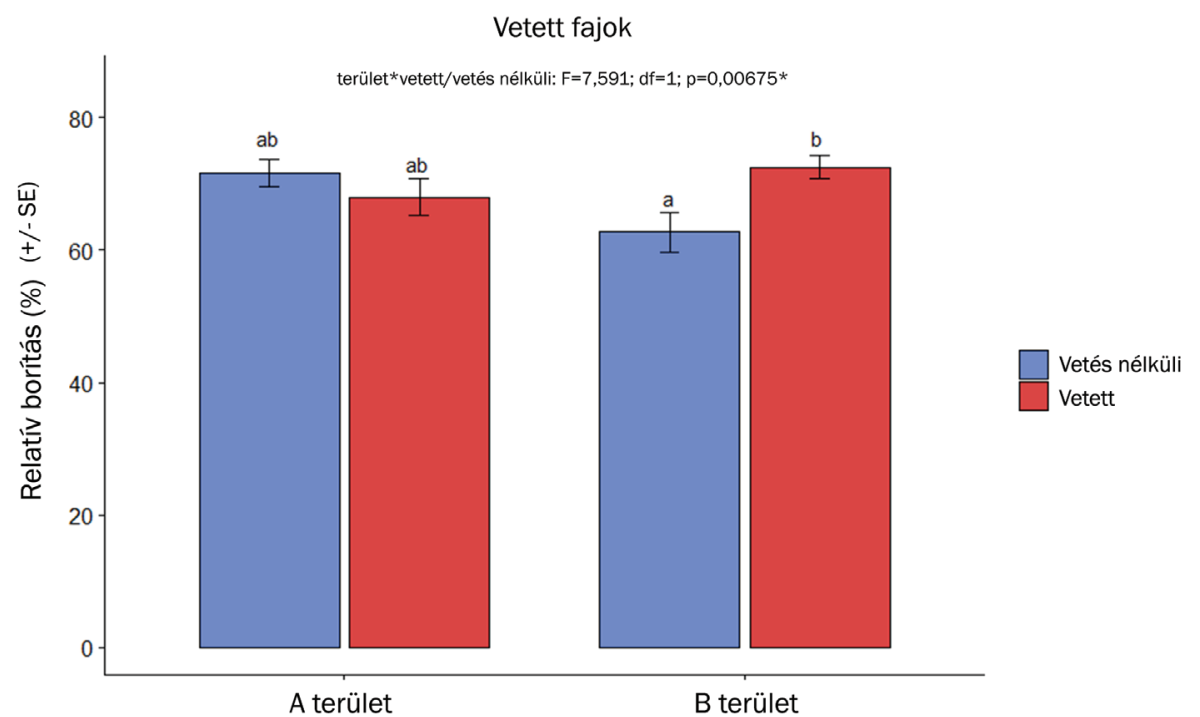

3. ábra. A vetett fajok relatív borítása a vetett és a vetés nélküli parcellákon az „A” és „B” terület esetében, 2019-ben. A szignifikáns különbségeket $(\mathrm{p}<0,05)$ eltérő kisbetűkkel jelöltük. 


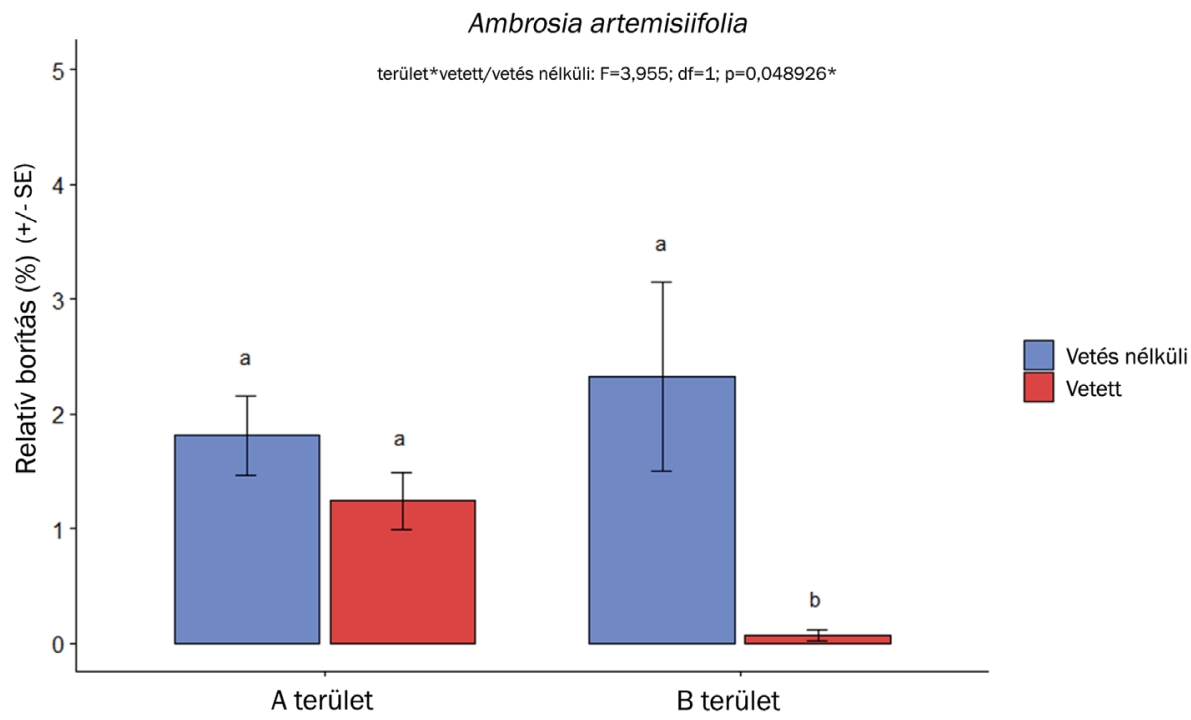

4. ábra. Az Ambrosia artemisiifolia relatív borítása a vetett és vetés nélküli parcellákon az „A” és „B” terület esetén, 2019-ben. A szignifikáns különbségeket $(\mathrm{p}<0,05)$ eltérő kisbetükkel jelöltük.

esetén, mely szerint a „B” terület vetett parcelláiban szignifikánsan alacsonyabb volt a faj relatív borítása $(0,07 \%)$, mint a nem vetett parcellákon $(2,32 \%)$ (4. ábra).

A táji környezetben a legfőbb élőhelyi különbség, hogy az „A” terület közelében a mai napig aktív mezőgazdasági tevékenység folyik, és a természetközeli gyepek és erdők aránya kisebb a „B” területhez képest (2. táblázat). Az ültetvények, másodlagos gyepterületek és beépített területek (főleg kisebb tanyák és utak) hasonló mértékben voltak jelen mindkét felhagyott szántó közelében.

A táji környezetben a legnagyobb egyedszámmal előforduló neofita fajok az A. artemisiifolia, Asclepias syriaca L., 1753, Conyza canadensis (L.) Cronquist, 1943, Ribes aureum Pursh, 1814 és a Robinia pseudoacacia L., 1753 voltak. A térképi ábrázoláson jól látható, hogy mindkét kísérleti terület környezete nagymértékben fertőzött az A. artemisiifolia és a Conyza canadensis fajokkal (5. és 6. ábra). A közönséges selyemkóró az „A” terület környezetében volt tömegesebb, míg a fehér akác és az aranyribiszke a „B” terület környezetében volt jellemző. Az özönfajok tömegessége szignifikánsan eltért a két terület esetében, az egyes égtáji irányok és a középponttól vett távolság alapján (3. táblázat). A két felhagyás közül az „A” terület táji környezetében szignifikánsan nagyobb volt az özönfajok tömegessége minden vizsgált változóra (3. táblázat). Az északi és keleti irányú transzektek mentén volt megfigyelhető a legtöbb inváziós faj. Mindkét felhagyás esetében a 9-10. kvadráttól kezdődően kezdett el emelkedni az özönnövények egyedszáma, vagyis csak a kísérleti területen kívül. 
2. táblázat. Táji kompozíció a kísérleti területek 500 méteres környezetében. Természetközeli erdők (TE), elsődleges (természetközeli) gyepek (TGy), másodlagos gyepek (MGy), vizes élőhelyek (V), agrár élőhelyek (A), erdészeti ültetvények (Ü), továbbá épített területek (É).

\begin{tabular}{|c|c|c|c|c|c|c|c|}
\hline & \multicolumn{7}{|c|}{ Élőhelyek kiterjedése (\%) } \\
\hline & $\mathrm{TE}$ & TGy & MGy & $\mathrm{V}$ & A & Ü & É \\
\hline $\begin{array}{c}\text { "A" } \\
\text { terület }\end{array}$ & 1,5 & 2,1 & 46,4 & 0 & 13,1 & 34,6 & 2,4 \\
\hline $\begin{array}{c}\text { "B" } \\
\text { terület }\end{array}$ & 10,8 & 9,4 & 43,1 & 1,5 & 0 & 30,4 & 4,8 \\
\hline
\end{tabular}

3. táblázat. Az özönnövények tömegessége (egyedszám $\left./ \mathrm{m}^{2}\right)$ a két felhagyott szántó táji környezetében és azok statisztikai különbsége negatív binomiális GLM alapján.

\begin{tabular}{|c|c|c|c|c|c|c|c|c|}
\hline & \multirow[t]{2}{*}{$\begin{array}{l}" \mathrm{~A} " \\
\text { terület }\end{array}$} & \multirow[t]{2}{*}{$\begin{array}{l}" \mathrm{~B} " \\
\text { terület }\end{array}$} & \multicolumn{2}{|c|}{ Terület } & \multicolumn{2}{|c|}{ Irányultság } & \multicolumn{2}{|c|}{ Távolság } \\
\hline & & & Chisq & p-érték & Chisq & p-érték & Chisq & p-érték \\
\hline Özönnövények & 17,2 & 6,5 & 392,31 & $\mathrm{p}<0,001$ & 121,86 & $\mathrm{p}<0,001$ & 437,43 & $\mathrm{p}<0,001$ \\
\hline $\begin{array}{l}\text { Egyéves } \\
\text { özönfajok }\end{array}$ & 7,6 & 2,5 & 395,54 & $\mathrm{p}<0,001$ & 138,90 & $\mathrm{p}<0,001$ & 361,18 & $\mathrm{p}<0,001$ \\
\hline $\begin{array}{l}\text { Ambrosia } \\
\text { artemisiifolia }\end{array}$ & 2,6 & 1,3 & 179,18 & $\mathrm{p}<0,01$ & 185,70 & $\mathrm{p}<0,01$ & 458,74 & $\mathrm{p}<0,01$ \\
\hline $\begin{array}{l}\text { Conyza } \\
\text { canadensis }\end{array}$ & 3,9 & 1,1 & 142,80 & $\mathrm{p}<0,001$ & 187,00 & $\mathrm{p}<0,001$ & 235,08 & $\mathrm{p}<0,001$ \\
\hline $\begin{array}{l}\text { Évelő } \\
\text { özönfajok }\end{array}$ & 9,3 & 3,3 & 496,02 & $\mathrm{p}<0,001$ & 169,96 & $\mathrm{p}<0,001$ & 476,10 & $\mathrm{p}<0,001$ \\
\hline $\begin{array}{l}\text { Asclepias } \\
\text { syriaca }\end{array}$ & 1,7 & 0,9 & 103,10 & $\mathrm{p}<0,001$ & 171,19 & $\mathrm{p}<0,001$ & 307,25 & $\mathrm{p}<0,001$ \\
\hline
\end{tabular}

\section{Diszkusszió}

Az alkalmazott kezelések közül a vetésnek volt a legnagyobb hosszú távú hatása, melynek még 16 évvel az első kezelések után is megmutatkoztak a jelei, főleg a $S$. borysthenica magasabb és az egyéves $A$. artemisiifolia alacsonyabb borításában. Ezek az eredmények összhangban állnak a korábban észleltekkel (Halassy et al. 2016). Hosszú távon azonban a vetett és nem vetett parcellák közötti egyes különbségek eltűntek, pl. a fajgazdagság, az edényes növények borítása és a célfajok relatív borítása esetében. A fajok dominancia-sorrendje is változott az idő múlásával. 2008-ban a D. serotinus volt a domináns faj, ami akár 69\%-os borítást is elért a vetett és kaszált parcellákban. A kaszálás elmaradásával borítása jelentősen lecsökkent, helyét az erősebb kompetítor $F$. vaginata és a $S$. borysthenica vette át. 

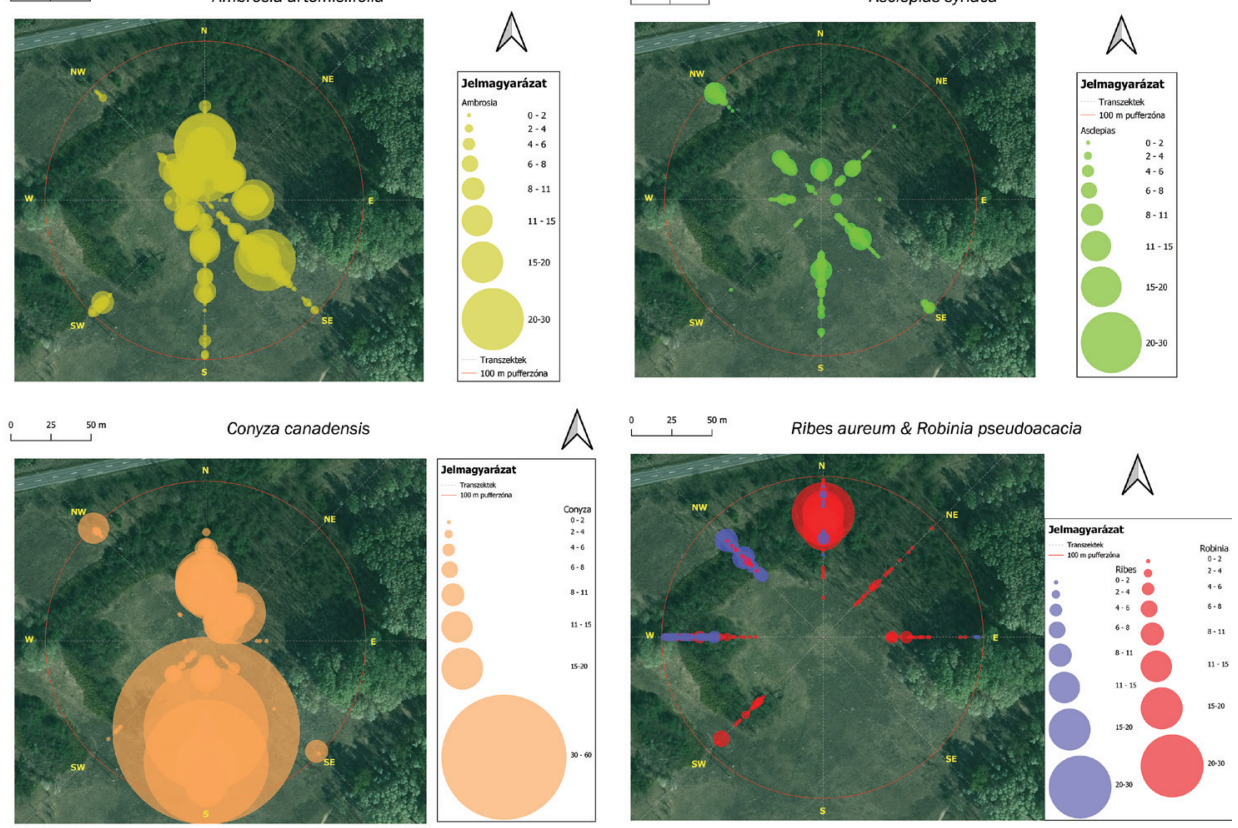

5. ábra. Az „A” terület környezetében rögzített özönnövények egyedszáma. Az adatokat 2020 szeptemberében rögzítettük és QGIS programmal ábrázoltuk.
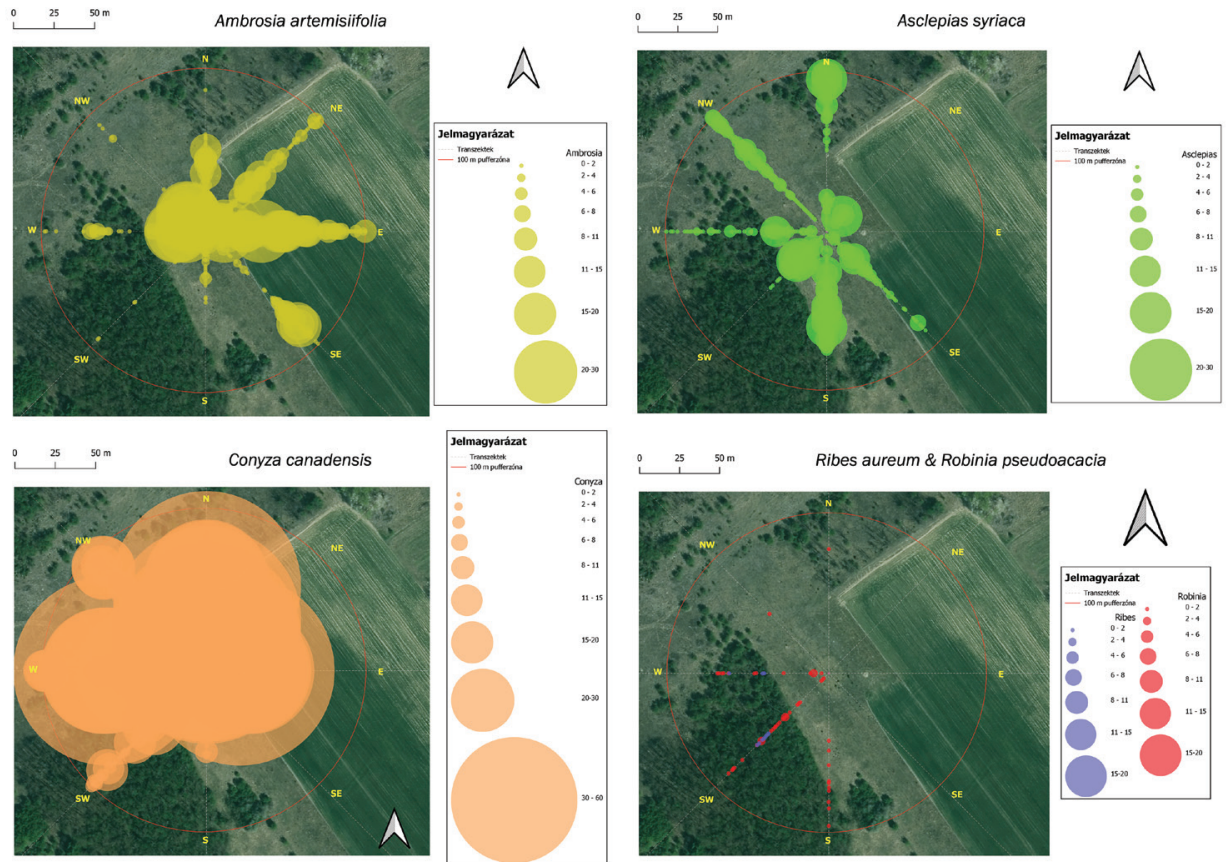

6. ábra. A „B” terület környezetében rögzített domináns özönnövények egyedszáma. Az adatokat 2020 szeptemberében rögzítettük és QGIS programmal ábrázoltuk.

Természetvédelmi Közlemények 27, 2021 
A domináns füfajok némileg visszaszorították a vetett szubordináns fajokat (pl. $K$. glauca), de nem szorították ki teljesen ezeket, és a spontán betelepült fajok is 15-20\%-os relatív borítást tudtak elérni (Llumiquinga et al. 2021). Bár referenciaadataink ebben a kísérletben nem voltak, összességében a 2019-re elért állapot jobb, mint a korábbi restaurációs beavatkozások során, ahol magvetést nem alkalmaztunk (Halassy et al. 2021, Reis et al. 2021). Ennek alapján javasoljuk a diverz, domináns füveket és néhány szubordinált fajt is tartalmazó keverék vetését nyílt homoki gyepek felhagyott szántókon történő restaurációjára.

Fontos megjegyezni, hogy a korai vetés lényeges szerepet játszott az özönnövények terjedésének visszaszorításában, még hosszú távon is. Ez föként az $A$. artemisiifolia elnyomását jelentette, ami fontos eredmény, hiszen az ürömlevelü parlagfü erősen allergén pollenje miatt súlyos egészségügyi gondokat okoz szerte Európában, és jelenléte elsősorban a talaj zavarásával függ össze (Kröel-Dulay et al. 2019). Hosszú távon a vetett fajok a szomszédos parcellákra is átterjedtek, ami a célfajok dominanciájához vezetett mindkét területen a vetett és nem vetett parcellákon egyaránt. Ez alapján, amennyiben a rendelkezésre álló magforrások korlátozottak, nagyobb területek restaurációja esetén a sávokban történő vetés is jó eredményekre vezethet hosszabb távon.

A kaszálás, ami a második legfontosabb kezeléstípus volt rövid távon (Halassy et al. 2016, 2019) hosszú távon csak kisebb hatást gyakorolt. A kaszálást gyakran használják domináns fajok kontrollálására, hogy a gyepszőnyeget megnyitva növeljék a fajdiverzitást (Maron és Jefferies 2001). Esetünkben rövid távon alacsonyabb borítást értünk el a kaszálás hatására (Halassy et al. 2016), de hosszú távon a kaszálás ellenkező hatást váltott ki, ami miatt a fajgazdagság várt növekedése elmaradt. Ez azt jelenti, hogy a nyílt homokgyepek esetén a területkezelés során az első években rendszeres, a későbbi években nem túl gyakori (pl. négy-ötévente történő) kaszálás alkalmazandó a fajgazdagság megtartásához (Kelemen et al. 2014).

Rövid távon a szénforrás-adagolás csökkentette az ásványi nitrogént a talajban, aminek a hatása megmutatkozott a mohák borításának csökkenésében, valamint a szabad talajfelszín növekedésében is (Halassy et al. 2016). Ezek a hatások azonban csak ideiglenesnek bizonyultak, ahogy korábbi vizsgálatok alapján erre számítani lehetett (Perry et al. 2010, Halassy et al. 2021), és hosszú távon eltüntek. Kisebb kiterjedésű friss felhagyások esetén ez a módszer is előnyösen alkalmazható, elsősorban az egyéves nitrogénigényes gyomok, akár özönfajok visszaszorítására is, vetéssel kiegészítve.

Eredményeink megerősítették a területspecifikus vegetációfejlődés tényét. A legtöbb vizsgált növényzeti mutató jelentős különbségeket mutatott a két terület között. Ezek az eredmények feltehetőleg összefüggésben vannak a felhagyások 
óta eltelt idővel, ami a fajösszetétel legfontosabb meghatározója volt Csecserits et al. (2011) a régióban végzett tanulmánya alapján. Ugyanakkor ez a tényező nem különíthető el a táji hatástól (Prach et al. 2013), miszerint az egyes felhagyott területek fajösszetétele akár teljes mértékben a környező területek gyepmaradványainak függvényében változhat. Esetünkben az idősebb felhagyás táji környezetében nagyobb arányban voltak jelen a maradványgyepek, melyek kiváló forrásai a célfajok propagulumainak. Ezzel szemben a közepes korú felhagyás esetében a művelt földek és ültetvények jelenléte az özönnövények terjedésének a kockázatát hozhatja magával (Csecserits et al. 2016). A transzekt-vizsgálat alátámasztotta, hogy a közepes korú felhagyás környezete fertőzöttebb volt özönfajokkal, elsősorban az ültetvények irányában.

Eredményeink alapján az alábbi kezelési módokat javasoljuk homoki gyepek regenerációjának felgyorsítására a felhagyott szántókon: A terjedési korlát sikeresen megszüntethető fajszegény, de füfajokat és virágos növényeket egyaránt tartalmazó magkeverék korai vetésével. Továbbá, nincs szükség arra, hogy egész területeket bevessünk, amikor homoki gyepeket kívánunk helyreállítani felhagyott szántókon, hanem elég kisebb, néhány négyzetméteres ún. „vetési ablakokat” (Valkó et al. 2016b) elszórtan alkalmazni, mivel a vetett fajok képesek elterjedni a szomszédos területeken is. A célfajok terjedése és a gyepek diverzifikációja érdekében további beavatkozásokra lehet szükség (Bartha et al. 2003, Kelemen et al. 2014). A jelenlegi és korábbi (Halassy et al. 2016, 2019) kutatásaink alapján a kaszálás vagy a szénforrás-adagolás egyaránt alkalmas ún. „megtelepedési ablakok" létrehozására, amik segítik az új betelepedéseket. A beavatkozások tervezésénél azonban figyelembe kell venni a táji környezetet is, mivel amennyiben a tájban erős az inváziós nyomás, az új betelepedők elsősorban a nemkívánatos özönnövények lesznek (Reis et al. 2021).

Köszönetnyilvánitás - A kutatást a Nemzeti Kutatási, Fejlesztési és Innovációs Hivatal támogatta (NKFIH FK127996).

\section{Irodalomjegyzék}

Bakker, J. P., Berendse, F. (1999): Constraints in the restoration of ecological diversity in grassland and heathland communities. Trends in Ecology and Evolution 14: 63-68. https://doi.org/10.1016/ s0169-5347(98)01544-4

Balogh, L., Dancza, I., Király, G. (2004): A magyarországi neofitonok időszerü jegyzéke, és besorolásuk inváziós szempontból. In Mihály, B., Botta-Dukát, Z. (szerk.): Biológiai inváziók Magyarországon: Özönnövények. A KvVM Természetvédelmi Hivatalának tanulmánykötetei 9. TermészetBƯVÁR Alapítvány Kiadó, Budapest, pp. 61-92. 
Bartha, S., Meiners, S. J., Pickett, S. T. A., Cadenasso, M. L. (2003): Plant colonization windows in a mesic old field succession. Applied Vegetation Science 6: 205-212. https://doi.org/10.1111/ j.1654-109X.2003.tb00581.x

Clark, A. (2017): Old fields. Oxford Bibliographies in Ecology. https://doi.org/10.1093/ obo/9780199830060-0188

Cramer, V. A., Hobbs, R. J., Standish, R. J. (2008): What's new about old fields? Land abandonment and ecosystem assembly. Trend in Ecology and Evolution 23: 104-112. https://doi.org/10.1016/j. tree.2007.10.005

Cramer, V. A., Hobbs, R. J. (eds.) (2007): Old fields: Dynamics and Restoration of Abandoned Farmland. Island Press, Washington, D.C., 334 p. https://doi.org/10.5860/choice.45-4977

Csathó, A. I. (2011): Az elsődleges és másodlagos mezsgyék növényzetének összehasonlító vizsgálata a Battonyai Gránic és Csárda-dűlő példáján. Tájökológiai Lapok 9(2): 345-356.

Csecserits, A., Botta-Dukát, Z., Kröel-Dulay, Gy., Lhotsky, B., Ónodi, G., Rédei, T., Szitár, K., Halassy, M. (2016): Tree plantations are hot-spots of plant invasion in a landscape with heterogeneous land-use Agriculture. Ecosystems and Environment 226: 88-89. https://doi.org/10.1016/j. agee.2016.03.024

Csecserits, A., Czúcz, B., Halassy, M., Kröel-Dulay, Gy., Rédei, T., Szabó, R., Szitár, K., Török, K. (2011): Regeneration of sandy old-field in the forest steppe region of Hungary. Plant Biosystems 145: 715-729. https://doi.org/10.1080/11263504.2011.601340

Csontos, P., Kalapos, T., Tamás, J. (2016): Comparison of seed longevity for thirty forest, grassland and weed species of the Central European flora: Results of a seed burial experiment. Polish Journal of Ecology 64(3): 313-326. https://doi.org/10.3161/15052249PJE2016.64.3.002

Davis, M.A., Grime, J. P., Thompson, K. (2000): Fluctuating resources in plant communities: A general theory of invasibility. Journal of Ecology 88: 528-534. https://doi.org/10.1046/j.13652745.2000.00473.x

Halassy, M., Botta-Dukát, Z., Csecserits, A., Szitár, K., Török, K. (2019): Trait-based approach confirms the importance of propagule limitation and assembly rules in old-field restoration: Propagule limitation and assembly rules in restoration. Restoration Ecology 27: 840-849. https:// doi.org/10.1111/rec.12929

Halassy, M., Kövendi-Jakó, A., Reis, B. P., Szitár, K., Seyidova, Z., Török, K. (2021): N immobilization treatment revisited: a retarded and temporary effect unfolded in old field restoration. Applied Vegetation Science 24: e12555. https://doi.org/10.1111/avsc. 12555

Halassy, M., Singh, A., Szabó, R., Szili-Kovács, T., Szitár, K., Török, K. (2016): The application of a filter-based assembly model to develop best practices for Pannonian sand grassland restoration. Journal of Applied Ecology 53: 765-773. https://doi.org/10.1111/1365-2664.12618

Kelemen, A., Török, P., Valkó, O., Deák, B., Miglécz, T., Tóth, K., Ölvedi, T., Tóthmérész, B. (2014): Sustaining recovered grasslands is not likely without proper management: vegetation changes after cessation of mowing. Biodiversity and Conservation 23: 741-751. https://doi. org/10.1007/s10531-014-0631-8

Kövendi-Jakó, A., Csecserits, A., Szitár, K., Halassy, M., Hülber, K., Wrbka, T., Török, K. (2019): Three years of vegetation development worth 30 years of secondary succession in urbanindustrial grassland restoration. Applied Vegetation Science 22: 138-149. https://doi.org/10.1111/ avsc. 12410

Kröel-Dulay, Gy., Csecserits, A., Szitár, K., Molnár, E., Szabó, R., Ónodi, G., Botta-Dukát, Z. (2019): The potential of common ragweed for further spread: invasibility of different habitats and the role of disturbances and propagule pressure. Biological Invasions 21: 137-149. https:// doi.org/10.1007/s10530-018-1811-3

Llumiquinga, Y. B., Reis, B. P., Sáradi, N., Török, K., Szitár, K., Halassy, M. (2021): Long-term results of initial seeding, mowing and carbon amendment of the restoration of Pannonian sand grassland on old-fields. Tuexenia 41: 361-379. https://doi.org/10.14471/2021.41.013 
Maron, J. L., Jefferies, R. (2001): Restoring enriched grasslands: Effects of mowing on species richness, productivity, and nitrogen retention. Ecological Applications 11(4): 1088-1100. https://doi. org $/ 10.2307 / 3061014$

Mihók, B., Biró, M., Molnár, Zs., Kovács, E., Bölöni, J., Erős, T., Standovár, T., Török, P., Csorba, G., Margóczi K., Báldi, A. (2017): Biodiversity on the waves of history: Conservation in a changing social and institutional environment in Hungary, a post-soviet EU member state. Biological Conservation 211: 67-75. https://doi.org/10.1016/j.biocon.2017.05.005

Perpiña, C., Kavalov, B., Diogo, V., Jacobs, C., Batista, F. E., Lavalle, C. (2018): Agricultural Land Abandonment in the EU within 2015-2030. No JRC113718, JRC Working Papers, Joint Research Centre (Seville site), https://EconPapers.repec.org/RePEc:ipt:iptwpa:jrc113718.

Perry, L. G., Blumenthal, D. M., Monaco, T. A., Pashcke, M. W., Redente, E. F. (2010): Inmobilization nitrogen to control plant invasion. Oecologia 163: 13-24. https://doi.org/10.1007/s00442$\underline{010-1580-\mathrm{x}}$

Pinheiro, J., Bates, D., DebRoy, S., Sarkar, D., Heisterkamp, S., Van Willigen, B. (n.d.) (2017): Package 'nlme'. Linear and Nonlinear Mixed Effects Models. Version 3-1. https://cran.r-project. org/web/packages/nlme

Prach, K., Jongepierová, I., Rehounková, K. (2013): Large-scale restoration of dry grasslands on exarable land using a regional seed mixture: Establishment of target species. Restoration Ecology 21: 33-39. https://doi.org/10.1111/j.1526-100X.2012.00872.x

R Core Team (2019): R: A language and environment for statistical computing. R Foundation for Statistical Computing, Vienna. https://www.R-project.org/

Reis, B. P., Kövendi-Jakó, A., Szitár, K., Török, K., Halassy, M. (2021): Long-term effect of mowing on the restoration of Pannonian sand grassland to replace invasive black locust plantation. Restoration Ecology 29(S1): e13152. https://doi.org/10.1111/rec.13152

Török, K., Szili-Kovács, T., Halassy, M., Tóth, T., Hayek, Z., Paschke, M. W., Wardell, L. J. (2000): Immobilization of soil nitrogen as a possible method for the restoration of sandy grassland. Applied Vegetation Science 3: 7-14. https://doi.org/10.2307/1478913

Török, K., Szitár, K., Halassy, M., Szabó, R., Szili-Kovács, T., Baráth, N., Paschke, M. W. (2014): Long-term outcome of nitrogen immobilization to restore endemic sand grassland in Hungary. Journal of Applied Ecology 51: 756-765. https://doi.org/10.1111/1365-2664.12220

Török, P., Deák, B., Vida, E., Valkó, O., Lengyel, Sz., Tóthmérész, B. (2010): Restoring grassland biodiversity: Sowing low-diversity seed mixtures can lead to rapid favourable changes. Biological Conservation 143: 806-812. https://doi.org/10.1016/j.biocon.2009.12.024

Török, P., Helm, A., Kiehl, K., Buisson, E., Valkó, O. (2018): Beyond the species pool: modification of species dispersal, establishment, and assembly by habitat restoration. Restoration Ecology 26: S65-S72. https://doi.org/10.1111/rec.12825

Valkó, O., Deák, B., Török, P., Kelemen, A., Miglécz, T., Tóth, K., Tóthmérész, B. (2016a): Abandonment of croplands: problem or chance for grassland restoration? Case studies from Hungary. Ecosystem Health and Sustainability 2: e01208. https://doi.org/10.1002/ehs2.1208

Valkó, O., Deák, B., Török, P., Kirmer, A., Tishew, S., Kelemen, A., Tóth, K., Miglécz, T., Radócz, Sz., Sonkoly, J., Tóth, E., Kiss, R., Kapocsi, I., Tóthmérész, B. (2016b): High-diversity sowing in establishment gaps: a promising new tool for enhancing grassland biodiversity. Tuexenia 36 : 359-378. https://doi.org/10.14471/2016.36.020

Valkó, O., Deák, B., Török, P., Tóth, K., Kiss, R., Kelemen, A., Miglécz, T., Sonkoly, J., Tóthmérész, B. (2021): Dynamics in vegetation and seed bank composition highlight the importance of post-restoration management in sown grasslands. Restoration Ecology 29(S1): e13192. https:// doi.org/10.1111/rec.13192

Zuur, A., Ieno, E. N., Walker, N., Saveliev, A. A., Smith, G. M. (2009): Mixed Effects Models and Extensions in Ecology with R. Springer, New York, 580 p. 


\title{
Long-term success of sand grassland regeneration on abandoned croplands: the impact of initial restoration interventions and the surrounding landscape
}

\author{
${\text { Nóra Sáradi }{ }^{*} \text {, Yesenia Belén Llumiquinga² }}^{2}$ Bruna Paolinelli Reis ${ }^{2}$, \\ Katalin Török ${ }^{3}$, Katalin Szitár ${ }^{3}$, Edina Csákvári ${ }^{3}$ \& Melinda Halassy ${ }^{3}$ \\ ${ }^{1}$ Hungarian University of Agriculture and Life Sciences, Institute of Crop Production, \\ H-2100 Gödöllö, Páter Károly u. 1, Hungary
}

${ }^{2}$ Eötvös Loránd University, Department of Plant Systematics, Ecology and Theoretical Biology, H-1117 Budapest, Pázmány Péter sétány 1/C, Hungary

${ }^{3}$ Centre for Ecological Research, Institute of Ecology and Botany, H-2163 Vácrátót, Alkotmány u. 2-4, Hungary

*E-mail: saradi.nora@ecolres.hu

\begin{abstract}
We evaluated the efficacy of three treatment methods in the restoration of sandy grasslands on abandoned fields, 16 years after the initial interventions, in Kiskunság, Central Hungary. We used species richness, vascular plant cover, and the relative cover of target and invasive plant species as indicators. The treatments were conducted on two fields abandoned at different times, between 2002 and 2008. We also investigated the habitat composition and invasion level of the surrounding landscapes. In the long run, seeding proved to be the most effective method for the restoration of sandy grasslands on abandoned fields. Mowing and carbon amendment are recommended as supplementary treatments. Most of the analyzed indicators showed site-specific development, which may be related to the characteristics of the surrounding landscape. Based on our results, we suggest that the restoration of old fields can be triggered by using small seed introduction units.
\end{abstract}

Keywords: grassland restoration, invasive plants, abandoned fields, sand steppe, long-term monitoring 